\title{
Qardhul Hasan in The Perspective of Islamic Law on Baitul Maal Wa Tamwil (BMT) and The Implementation
}

\author{
Merly Cahya Putri ${ }^{1}$, Ana Nur Hasanah ${ }^{2}$, Khufyah Robe' Nur ${ }^{3}$, Abdul And Qadir $^{4}$ \\ \{ananh2710@gmail.com ${ }^{1}$, merlycp01@gmail.com ${ }^{2}$, alifwahyufaisol@gmail.com ${ }^{3}$, \\ abdul_flowers@yahoo.com ${ }^{4}$ \} \\ ${ }^{1,2,3,4}$ Graduate School, State Institute for Islamic Studies of Metro, Indonesia
}

\begin{abstract}
In implementing Islamic Financial Institutions such as Baitul Maal wa Tamwil (BMT) there are various ways to raise funds and distribute funds. Funds are collected through deposits and wadiah deposits. Qardhul Hasan financing is the orientation of the function of the Islamic Financial Institution (Baitul Maal Wa Tamwil) as a social institution. Qardhul hasan is a soft loan given on the basis of mere social obligations. The mechanism for implementing Qardhul Hasan is solely aimed at providing assistance to meet the needs of small communities. Thus it can be seen that the form of loans through Qardhul Hasan is in accordance with the principles of Islamic economic law, the potential sources of funding for Qardhul Hasan are quite large if used and managed optimally and its implementation is very beneficial to the community.
\end{abstract}

Keywords : Qardhul Hasan, Islamic Law, BMT

\section{Introduction}

Humans as social beings have goals and principles, and in life between humans there is a relationship that can not be separated, especially in terms of muamalah. One human needs another human to fulfill his life needs. In the journey of humans to happiness in life in the world with a family, has a life companion and offspring.[1] A man who is responsible and has a strong religion will look for various halal ways to meet the needs of life for himself and his family.

The majority of the population in Indonesia are Muslims who in carrying out their daily activities should make the Islamic Shari'a as a foundation in order to fulfill life and prosperity together, both for themselves and others. Islam commands a Muslim to work as hard as he can in finding halal sustenance that is good again.[2] To meet the needs of a person and his family, someone can borrow from a private person. If the need is for business capital, one can borrow from formal and informal institutions. In this way someone will get income to meet their needs. At present, various programs have been developed on various Islamic financial institutions that can be utilized for the benefit of the community. Along with the increasing level of community needs in Indonesia both in terms of food clothing and shelter, the growth of small businesses in the community to meet their respective needs. The emergence of these businesses certainly can not be separated from the capital in carrying out its activities. In obtaining capital, the entrepreneur will look for financial institutions that can help in terms of financing (finance).

With regard to capital, for small economy businesses, capital is a chairal aspect. Small businesses in general have very limited capital, thus contributing greatly to the slow accumulation of capital that causes these small businesses to have no capital reserves. As a 
result, when there is a lethargy small businesses die out.[3] Capital constraints for small entrepreneurs generally cannot be met by modern banking. In general they are not bankable to decide on their credit. So many small businesses have capital difficulties. This condition further widens the gap between small businesses and the informal sector with the formal banking industry.[4] From this journey, the concept of economy was born based on the values of empowerment and community development, especially the lower middle class, namely the concept of social economy. The concept of populist economics is the idea of the way, nature, and goals of development with the main objective of improving the lot of people in rural areas. This concept has made important changes towards progress, especially towards breaking down ties and barriers which hold the majority of the Indonesian people in a state of flaws and limitations.

One of the non-bank Islamic Financial Institutions that channel funds to the public is BMT (Baitul Maal Wa Tamwil). This is a financial system that is more suited to the conditions of small businesses and is in accordance with Sharia. In its operation BMT does not only play a role in channeling funds to the community and the middle class who have collateral only. But it also distributes funds to small entrepreneurs or underprivileged communities who have potential business skills. The main advantage of BMT from its social activities is the Qardhul Hasan financing scheme. This product is only for people who are less able to build and develop their businesses.[5]

BMT is one of the non-bank Islamic financial institutions that is willing to help entrepreneurs in terms of capital. And Qardhul Hasan is a social loan that is given without interest and is soft because it is only demanded to return the initial capital with the same amount as the loan received by members in a way a period of time determined or agreed upon by the Islamic financial institution.[6] In subsequent developments for economic empowerment as an effort to arouse the activities of small businesses, a Baitul maal was formed which concentrated on fostering and developing small businesses with a sharia system with various results and is a commercial institution.[7]

Many Islamic banks are spread throughout Indonesia, but in reality have not been able to touch the middle to lower classes. The lower middle class community in general is almost untouched and is not considered to have the potential for funding by formal financial institutions, thus causing a slowdown in economic growth. In fact, the majority of the middle to lower classes are trapped borrowing from moneylenders.[8]

Qardhul hasan is one of the products contained in social mission. The existence of social community missions will improve good image and increase public loyalty to BMT. A qardh contract is a contract that facilitates the transaction of borrowing a number of funds without charging interest for the funds borrowed by members.[9] The qardh transaction is basically a social transaction because it is not followed by taking profits from the funds lent.

Basically qardhul hasan loans are given to those who need short-term consumer loans for very urgent purposes and also small entrepreneurs who lack funds but have very good business prospects. Therefore the author wants to see how the perspective of Islamic economic law views Qardhul Hasan and its implementation in society. The legal basis used in the implementation of Qardhul Hasan is based on the Al-Quran verse in accordance with the National Sharia Council Fatwa No. 19 / DSN-MUI / IX / 2000.

Ijma '. The scholars have agreed that Qardhul Hasan is permissible. This cleric agreement is based on human nature who can not live without the help and assistance of his brother. Nobody has everything that is needed. Therefore, lending has become one part of life in this world. And, Islam is a religion that is very concerned about all the needs of its people. Based 
on the DSN Fatwa, then the consideration of the National Islamic Council establishes Qardhul Hasan as a legitimate economic system according to Islam.

The basis of the argument in this verse is that we are diseur to "lend to God", meaning to spend wealth in the way of God. In harmony with lending to God, we are also designed to "lend to fellow human beings", as part of community life.[10]

Lending that is beneficial for fellow Muslims who use the Qardhul Hasan agreement is also included in the above verse. These loans can now be in the form of venture capital, such as those already available in institutions that have a loan assistance program for poor people by using the Qardhul Hasan agreement. While hadits in accordance with the Qardhul Hasan agreement are as follows:

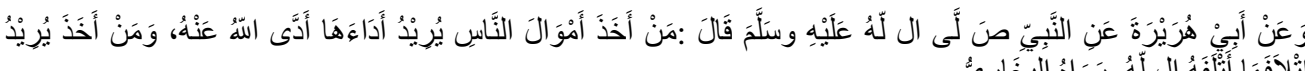

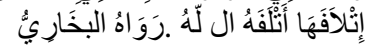

Meaning: "From Abu Hurairah Radhiyallahu Anhu, from the Prophet sallallaahu Alaihi wa Sallam said, "whoever takes the property of another person with the intention of returning it, then Allah will help it to be able to return it; and whoever takes it with the intent to spend it, then Allah will destroy it." (Narrated by Al-Bukhari).[11]

The purpose of the hadith above is to take the property of others by way of debt and take care of those who have the intention to return it, then Allah will provide convenience to repay the debt. And if the treasure is taken to be spent then God will complicate all his affairs and desires in the world. In the hadith there is also motivation to improve intentions and avoid the opposite, and explain that the core of the action lies in that. Whoever owes with the intention to pay it off surely Allah helps pay it off.[12]

\section{Literature Review}

\subsubsection{Baitul Maal wa Tamwil (BMT)}

BMT is the abbreviation of the word Integrated Business Centers or Baitul Maal wa Tamwil, which is a Microfinance Institution (LKM) that operates based on sharia principles. BMT as the name implies consists of two main functions, namely:[13]

1. Baitul maal (house of treasures), receive deposits of zakat, infaq and alms and optimize their distribution in accordance with regulations and mandate.

2. Baitul tamwil (property development house), conducts productive business development activities and investments in improving the economic quality of micro entrepreneurs by, among other things, encouraging saving activities and supporting financing of economic activities.

Thus, the existence of BMT can be seen to have two main functions, namely as a medium for the utilization of worship assets such as zakat, donation, alms and endowments, and can also be of a productive nature like a bank. As a financial institution, BMT also functions as an economic institution. As a financial institution, BMT has the duty to collect funds from the community (BMT members) and channel funds to the community (members of BMT). Meanwhile, as an economic institution, BMT has the right to carry out economic activities, such as managing trade, industry and agriculture. 


\subsubsection{Qardhul Hasan}

Definition of Qardh (Loan) according to fiqh, qardh or iqradh etymologically means loan. In term of muamalah is "have something that must be returned with the same substitute.[14]

Qardhul hasan comes from the concept of qardh which was in the time of the Prophet Muhammad. Literally it means "to cut off a portion." While terminologically means the exchange of an asset or object with an obligation for the recipient to bear the same portion of what he received from the lender, to be utilized by the recipient of the item.[15] The definition of qardhul hasan according to several sources as follows:

1. Qardh is a benevolent / soft loan without compensation, usually for the purchase of goods that can be estimated and replaced according to weight, size and amount.[6]

2. Al-Qardh is the provision of assets to other people who can be billed or demanded again in accordance with the amount of money lent, without any additional or compensation requested by the Sharia Bank / Islamic Financial Institution.

3. Al-Qardh is the property given by the creditor (muqridh) to the recipient of the debt (muqtaridh) and then returned to him (muqrid) as received, when he has been able to pay it.[16]

4. In the classical jurisprudence literature al-qardh is categorized as' aqad ta'awuni or a contract of mutual assistance and not a commercial transaction.[10]

From the above understanding the authors conclude that what is meant by qardhul hasan is a product in which this product is a ta'awun product (please help) where these funds are sourced from zakat, infaq and alms which are socialist and not for consumptive needs only, but for urgent needs such as medical expenses, education and others.

The recipient of Qardhul Hasan is only obliged to repay the principal loan amount without being required to provide any additional funds. However, loan recipients may, in their sole discretion, pay more than the money they borrow as a sign of gratitude to the lender. But this must not be agreed in advance.[17]

Qardhul Hasan or benevolent loan is a soft loan given on the basis of social obligations only, where the borrower is not required to return anything except loan capital.[18] Basically Qardhul Hasan is a social loan that is given in a benevolent manner without any charge, except the return of original capital.

In a qard agreement, a loan gives a loan to the recipient of the loan provided that the loan recipient will return the loan in accordance with the agreed period of time with the same amount as the loan received. Thus the recipient of the loan is not required to provide additional loans.[19]

Qardhul Hasan belongs to the Tabarru contract '. Tabarru contract 'is done with the aim of helping in order to do good (tabarru' comes from the word birr in Arabic, which means goodness). In a tabarru agreement, the party doing good is not entitled to require any compensation to other parties.[20]

Basically the Qardhul Hasan loan was given to:

1. Those who need short-term consumer loans for very urgent purposes.

2. Small entrepreneurs who lack funds but have very good business prospects. [21]

Qard that is needed to help small businesses and social needs, can be sourced from zakat, infaq, and sadaqah funds. Qardhul Hasan is also devoted to helping provide loans to 
businesses in small sectors which generally have difficulty developing their businesses. Providing cash loans to Qardhul Hasan without incurring any costs except administrative costs in the form of all costs required for the validity of the debt agreement. Such as stamp duty, notarial deed fees, feasibility study fees, and so on.

In essence qard is help and affection for those who borrow. Qard is not a means to seek profits for lenders, in which there are no rewards and excess returns. But what is contained in this qard $\}$ is to contain human and social values that are full of affection to fulfill the lender's intentions. If there is a profit taking by the party lending capital or assets, it can cancel the qard contract.[22]

\subsection{Implementation of Qardh in Baitul Maal wa Tamwil (BMT)}

Qardh as one of the financial instruments in Islam has implemented in several Sharia Financial Institutions. Among the Sharia Financial Institutions are Sharia Banks, Baitul Maal wa Tamwil (BMT) and Sharia Savings and Loans Unit. But what will be discussed by the author is only the implementation of qardh in BMT as follows:

Besides being identified as a financial or business institution, BMT is also often understood as a social institution. On one occasion the BMT could invest its funds to further develop its business, but at another time the BMT could also develop itself to help in solving social problems, especially the community's consumptive needs. In the first case BMT acts as bayt altamwil and in the second case BMT acts as bayt al-mal. In the first role, BMT as bayt al-mal, BMT can be identified as a social institution, an institution whose role is to help solve social problems, especially economic problems faced by the community. This means that how BMT can position itself as part of an institution that can advocate the problem of consumer needs that are consumptive.

The role of BMT can be realized in the form of issuing qardh products, namely loans provided by BMT to customers and customers only return the principal loan without any additions. This product is considered as a form of kindness given by BMT to the community, so the term used is often referred to as qardhul hasan. At the level of implementation, BMT acts as muqarridh (lender), while customers act as muqtaridh.[23]

Qardh at BMT, however, is part of a work mechanism that further emphasizes social and non-profit roles. However, this does not necessarily mean that BMTs have to lose as financial capital decreases. Therefore, the funds used for this qardh are not taken from BMT capital, but are taken from other funding sources, such as the results of the collection of zakat, donations and alms. Zakat, infaq and alms can come from alms, infaq and alms BMT itself or from outsiders who entrust alms, infaq and alms to BMT.

Efforts to minimize losses that may be experienced by BMT in qardh products can also be done by stipulating that administrative costs are fully borne by the customer. This is in line with what is stipulated in Fatwa DSN MUI Number 19 / DSN-MUI / IV / 2001 that administrative costs in qardh are charged to customers.

In addition, in an effort to minimize BMT losses due to negligence of customers in fulfilling their obligations, BMT has the right to request collateral from customers whose value is greater than the funds borrowed. If the customer cannot fulfill his obligations, then BMT can sell the customer's guarantee and take the amount of funds borrowed by the customer, while the excess is left to the customer. 


\section{Conclusions}

Based on the results of the search and discussion of Qardhul Hasan's analysis in the Perspective of Islamic Law on Baitul Maal wa Tamwil (BMT) and its implementation, it can be concluded that: Al Qardhul Hasan is a contract that is specialized in loans of assets that are measured and can be collected and is a mutual contract. help and not a commercial business transaction. Sources of qardh funds are taken from the LKS capital section, namely Baitul Maal wa Tamwil (BMT), Profit set aside, and other Institutions or individuals who entrust the distribution of infaq to BMT. One of the functions of Islamic Financial Institutions (LKS) including Baitul Maal wa Tamwil (BMT) is that besides being a commercial institution, it also participates in social activities that can optimally improve the economy, which is applied by channeling funds in the form of qardh. The financing of Qardhul Hasan in BMT is sourced from qardhul hasan financing funds originating from cooperative reserve funds obtained from the remaining profit sharing from other financing. The impact felt by members after receiving qardhul hasan financing is that it can help because they can pay tuition fees and other costs without the slightest addition in terms of amount and the time is not determined so it is not burdensome.

\section{References}

[1] M. B. Mustofa, "Hukum Nafkah Terhadap Keluarga pada Gerakan Dakwah Jama'ah Tabligh," Nizham, vol. 7, no. 1, p. 1, 2019.

[2] M. Dr. Abdurrachman Qadir, Zakat (Dalam Dimensi Mahdah Dan Sosial), 1st ed. Jakarta: PT. Raja Grafindo Persada, 2001.

[3] M. A. Adnan, "Evaluasi Performing Loan (NPL) Pinjaman Qardhul Hasan (Studi Kasus di BNI Syariah Cabang Yogyakarta),” Perbankan, vol. 10, no. 2, pp. 155-171, 2001.

[4] M. Ridwan, Managemen Baitul Maal Wa Tamwil, 1st ed. Yogyakarta, 2004.

[5] D. Riswandi, "Pembiayaan Qardhul Hasan Di Bank Syariah Mandiri Kota Mataram," Istinbath, vol. 14, no. 2, p. 253, 2015.

[6] Ascarya, Akad dan Produk Bank Syariah. Jakarta: PT. Raja Grafindo Persada, 2015.

[7] Mulyaningrum, "Peluang dan Tantangan dalam Pengembangan Lembaga Keuangan Mikro Syaria," Univ. Kebangs. Malaysia, p. 45, 2009.

[8] Muhammad, Bank Syariah: Problem dan Prospek Perkembangan di Indonesia. Yogyakarta: Graha Ilmu, 2005.

[9] R. Yaya, A. E. Martawireja, and A. Abdurahim, Akuntansi Perbankan Syariah Teori dan Praktik Kontemporer, 2nd ed. Jakarta: UII Press, 2014.

[10] Muhammad Syafi'i Antonio, Bank Syariah dari Teori ke Praktek. Jakarta: Gema Insani, 2001.

[11] I. Al-Buhari, Sahih al-Buhari bihasiyat al-Imam al-Sindi. Lebanon, 2008.

[12] M. bin I. A.-A. Ash-Shan'ani, Subulus Salam Syarah Bulughul Maram. Jakarta: Darus Sunnah Press, 2008.

[13] A. Soemitra, Bank dan Lembaga Keuangan Syariah, 1st ed. Jakarta: Kencana Prenade Media, 2009.

[14] W. Arintasari, "Analisis Sistem Pengendalian Intern Terhadap Keputusan Persetujuan Pembiayaan pada Koperasi Jasa Keuangan Syariah di Baitul Maal wa Tamwil Anda Salatiga," IAIN Slatiga, 2013.

[15] W. Zulayle, Financial Transaction in Islamic Jurisprudence. Dar al Fikr Mouaser, 
2003.

[16] Muslich and A. Wardi, Fiqih Muamalat. Jakarta: Amzah, 2010.

[17] S. R. Sjahdeni, Perbankan Syariah Produk - Produk dan Aspek-Aspek Hukumnya. Jakarta: Kencana Prenade Media, 2014.

[18] Muhammad, Sistem dan Prosedur Operasional Bank Syariah. Yogyakarta: UII Press, 2000.

[19] A. Drs. Ismail, MBA., Perbankan Syariah, 4th ed. Jakarta, 2017.

[20] A. Karim, BANK ISLAM : Analisis Fiqih dan Keuangan. Jakarta: PT. Raja Grafindo Persada, 2011.

[21] K. Perwataatmadja and M. S. Antonio, "Apa dan Bagaimana Bank Islam.”

[22] A. A. Hakim, Fiqih Perbankan Syariah. Bandung: Refika Aditama, 2011.

[23] Y. Janwari, Fikih Lembaga Keuangan Syariah. Bandung: Rosdakarya, 2015. 